\title{
Impact of Corporate Governance on Corporate Value: Research in Vietnam
}

\author{
Nguyen Thi Thanh Phuong ${ }^{1} \&$ Dang Ngoc Hung ${ }^{2}$ \\ ${ }^{1}$ Thuongmai University, Vietnam \\ ${ }^{2}$ Hanoi University of Industry, Vietnam \\ Correspondence: Dang Ngoc Hung, Hanoi University of Industry, Vietnam. E-mail: hungdangngockt@yahoo.com.vn
}

Received: February 1, 2020

Accepted: March 3, 2020

Online Published: March 9, 2020

doi:10.5430/rwe.v11n1p161

URL: https://doi.org/10.5430/rwe.v11n1p161

\begin{abstract}
The paper examines the impact of corporate governance (CG) on firm value (FV) of enterprises in Vietnam. We consider the GC issue from the individual aspects of each member of the Board of Directors (BOD). The research uses GLS regression model, data collected at energy enterprises listed on the stock market in Vietnam during the period 2008 - 2018, with 2937 observations. The research results have found that the size of the BOD has a direct impact on $\mathrm{FV}$, while it is interesting that the Board of Directors' independence has a direct impact on FV when measured by market value, but is in an inverse relation with $\mathrm{FV}$ if measured at book value. In addition, BOD chairperson cum $\mathrm{CEO}$ has an inverse impact on FV and female BOD members do not have an impact on FV. Further, the research results also prove that an enterprise's size is directly related with its value, whereas financial leverage is inversely related with the enterprise's value. Empirical research results serve as a useful basis for enterprises to increase their value, thus enabling the consideration of factors of the board of director at each enterprise.
\end{abstract}

Keywords: corporate governance, board of directors, corporate value

\section{Introduction}

Since the global economic crisis and the collapse of a series of large corporations in the world such as Lehman Brothers, Merrill Lynch, Enron, CIT Group, etc., the GC issue is frequently referred to and has become a research focus of enterprises around the world. This arouses a lot of doubts about the performance of the management system as well as whether the information disclosed by the listed enterprises is transparent, truthful and reasonable or not? Therefore, the relationship between GC and FV has been an issue of great interest to many researchers, particularly those in developed countries. When studying the impact of GC on FV, it is found by Black, Jang, \& Kim, 2006; Gompers, Ishii, \& Metrick, 2003, that GC has a significant inverse impact on FV. This was also found in research by Brown \& Caylor, 2004, when analyzing 2,327 enterprises in the United States, based on 51 GC-related factors provided by ISS (Institutional Shareholder Services). Studies by Lipton \& Lorsch, 1992; Mashayekhi \& Bazaz, 2008, show that the size of the board of directors is inversely related with FV, but when enterprises hire outside enterprises to run, FV will be increased. The relationship between the board structure and FV does not seem to be clear in this research. When the ownership of an enterprise focuses largely on an individual or organization, it will reduce the enterprise's representation costs and increase FV. However, in the case of CEO cum BOD chairperson, it will have a negative on FV. This conclusion is found in studies by Bhagat \& Black, 2002; Ehikioya, 2009. The relationship between GC and FV is also being studied and discussed in many developing countries such as the studies by Zabri, Ahmad, \& Wah, 2016; Arora \& Sharma, 2016; Dang, Vu, Ngo, \& Hoang, 2019.

This goal of this study is to examine the relationship between GC and FV to consolidate and supplement the results of previous studies. Based on studies by Black et al., 2006; Gompers et al., 2003; Brown \& Caylor, 2004; Lipton \& Lorsch, 1992; Mashayekhi \& Bazaz, 2008; Arora \& Sharma, 2016, this research paper will review the components of BOD size; BOD independence; BOD meeting frequency, CEO cum BOD chairperson, ratio of women on BOD and how other control variables, such as enterprise size and financial leverage, will affect FV?

Based on studies conducted in developed and developing countries, when considering the impact of each individual member of the BOD on FV is not identical, sometimes contradictory to each other, the cause of the difference is likely due to the very different measurement and the data from different markets. In a comprehensive manner, this research is 
based on data collected from 267 companies listed on the stock market in Vietnam during the period 2008-2018. The variables representing $\mathrm{FV}$ are measured in the aspect of book value, namely return of assets (ROA), earnings per share (EPS) and measured according to market value, namely Tobin's $Q$ and share price (PRICE).

\section{Theoretical Basis}

\subsection{Representation Theory}

Representation theory (M. C. Jensen \& Meckling, 1976) also known as theory of authorization focusing on the relationship between the owner (authorizer) and the authorized (representative). The representation issue will inevitably create a contradiction between the authorizer and the representative, between shareholder and owner. To resolve such contradiction, the manager will impact on accounting data, on the arising economic operations to ensure the harmonization of the parties' interests. Specifically, the theory of representation is in place to interpret the dual post of $\mathrm{CEO}$ and chairperson of the BOD, BOD size, BOD independence through the ratio of independent, non-executive members of the BOD, number of BOD meetings, number of members of monitoring committee, type of auditing company, state capital ownership, ownership of managed capital impacting on EQ.

\subsection{Theory of Stakeholders}

Theory of stakeholders is a point of view on management strategy and ethics, first introduced by Freeman, 1984. The central idea of this theory purports that the success of an organization depends on the relationship between the manager and stakeholders such as investors, creditors, workers, customers, suppliers, state and other entities involved in achieving corporate goals. The theory of stakeholders is widely applied by quite a few researchers to justify their research results. The theory of stakeholders that supports any company where the board of directors is large and varied will be suitable and convenient for linking the components. In addition to using the representation theory, the theory of stakeholders is also combined to explain the BOD factors that affect EQ.

\subsection{Signal Theory}

Signal theory was introduced by Spence, 1973. While studying the labor market, he found that hiring workers in an uncertain decision as the true capacities of workers are still unknown. Ross, 1977, observed that the inherent contradictions of shareholders and the manager make the manager focus on providing central signals to meet the basic information needs of users. In the financial market, the main relationship between shareholders and the manager is represented by return on investment, investors make economic decisions based on profitability indicators. On this theoretical foundation, studies expand into the financial market and find that highly profitable companies will use explanations to provide signals to improve their competitiveness. The manager is keenly aware of the quite basic principle: "A good signal can attract great interest from stakeholders such as investors, creditors, workers, customers, etc." They can absolutely choose the best time to make good information available or hide or delay the provision of adverse information to the outside or they can even perform tricks to change such adverse information.

\subsection{Resource Dependency Theory}

Pfeffer \& Salancik, 1978, introduced Resource dependency theory as a fundamental theory about the resource role of an enterprise's board of directors. They think that activities of organizations will be interdependent and resources will contribute to strengthening the corporate organization and operation functions. It is necessary for the board of directors to govern the dependency among organizations and ensure availability of the resources and information they need. Hillman \& Dalziel, 2003, suggested that an ideal board of directors should consist of many individuals with external links, such as business experts, support experts, and communities having an impact on the accessibility to resources necessary for the company. Theorists of resource dependency think that a BOD that is varied and with representatives of independent external members can improve corporate activities, especially when there is a major change in the operating environment (Nicholson \& Kiel, 2007; Hillman \& Dalziel, 2003). Enterprises with larger or more varied boards of directors will have more advantages to enjoy and maintain important resources such as human capital, social capital, legal knowledge (Xie, Davidson, \& DaDalt, 2003), (Peasnell, Pope, \& Young, 2005).

\section{Research Overview}

The relationship between corporate governance and firm value is a topic of interest to many researchers and there has been a great deal of research related to this topic. Some studies use a set of general indexes of corporate governance to measure the relationship between corporate governance and firm value. For example, the studies by Gompers et al., 2003; Core, Guay, \& Rusticus, 2006 set G-index to study this issue. However, most of these studies analyzed the relationship between firm value and a subset of variables in corporate governance such as BOD composition, BOD size, CEO dual position (Bhagat \& Black, 2002; Ehikioya, 2009; Lipton \& Lorsch, 1992; Mashayekhi \& Bazaz, 2008). 
Determining appropriate and optimal BOD size in an enterprise is an issue debated in many studies (Mashayekhi \& Bazaz, 2008; Ehikioya, 2009; Zabri et al., 2016; Detthamrong, Chancharat, \& Vithessonthi, 2017). Some researchers think that companies with small BODs will improve the corporate performance, thereby increasing firm value. Mashayekhi \& Bazaz, 2008, argued that enterprises with smaller BODs are more likely to be effective in management and supervision, making enterprises operate more effectively and increasing firm value. Zabri et al., 2016, also support small-sized BODs as they think that this will further facilitate the decision-making process thanks to the better coordination between the BOD members and less communicating issues arising. Larger BODs are often confronted with problems of communication and cohesion, which can lead to conflicts among the BOD members. On the other hand, the larger the type of business and corporate size, the more CEOs need consultations from the BOD members. For instance, companies operating in different sectors of the economy need to have many discussions and consultations from the BOD members (Ehikioya, 2009; Detthamrong et al., 2017). This will make it possible for the company to make more precise decisions. So, companies larger in size and operating in different areas will need larger BODs.

BOD independence is represented through the ratio of independent members to the total number of the BOD members. Brickley, Coles, \& Terry, 1994, found a positive relationship between BOD independence and the market value of these enterprises. Mashayekhi \& Bazaz, 2008, also found similar results when analizing the relationship between corporate governance and firm value indexes in Iran during the period 2005-2006. These studies show that when enterprises have many independent BOD members, the difference in the goals between the managers and shareholders will be reduced. This makes corporate activities more effective. However, many other studies do not find a clear relationship between BOD independence and corporate performance. Typically, the study by Yermack, 1996, pointed out that BOD independence has an insignificant impact on corporate activities. Fosberg, 1989, also did not find any relationship between the ratio of independent BOD members to corporate performance. Even the results of research by Bhagat \& Black, 2002 also show a negative correlation between BOD independence and firm value.

When the BOD members meet regularly, they will have many discussions about corporate issues, creating a better coordination in running as well as performing corporate duties. This conclusion was drawn from the study by Lipton \& Lorsch, 1992. Michael C Jensen, 1993, observed that when BOD meetings are not held regularly or only when the enterprise is in a difficult situation will make the enterprise lose its initiative and cannot provide timely adjustments to adapt to market changes. Sharing the same viewpoints in the studies above, Conger, Finegold, \& Lawler, 1998 suggested that the time and number of BOD meetings constitute an important factor for improving the BOD performance. Based on that, the BOD can make more timely and precise decisions, enabling to improve the performance and increase firm value. Nevertheless, Vafeas, 1999, noted that holding BOD meeting on a regular basis would cost enterprises a lot. For example, travel costs, remuneration for managers hired from the outside, expenses for time of members of the executive BOD if the meeting is ineffective, and other ensuing expenses. The issue of the relationship between the CEO cum chairperson of the BOD and firm value is also a topic of debate among researchers at present. Empirical studies of this issue show contradictory results. Some points of view purport that the CEO cum chairperson of the BOD will enable the corporate governance and management system to become better so that the corporate activities will be more effective and contribute to improving firm value. Research by Boyd, 1995, also showed that the CEO cum chairperson of the BOD actually improves the corporate performance and increases firm value. Whereas, many other researchers do not agree with the point of view above and argue that the positions of CEO and chairperson of the BOD must be separated (Ehikioya, 2009). The fact that one person assumes two roles at the same time will make corporate governance and management work overlapping, unclear, and in some cases, may give rise to conflicts within the enterprise. This obviously has an adverse impact on the corporate activities. In support of the viewpoint above, Rechner \& Dalton, 1991, assumes that enterprises should separate the positions of CEO and chairperson of the BOD. Because, when having a professional and independent leader, the enterprise can make more precise decisions, standardize the governance and management system, and build trust with shareholders. Along with the two points of view above, there also are a number of studies in which no significant difference in the performance has been found between enterprises with CEO cum chairperson of the BOD and enterprises where these two positions are separated, as the study by Daily \& Dalton, 1997, for instance.

Overall, the results of previous studies, though there was a difference, show the relationship between corporate governance and firm value. Differences in the level and direction of the impact of corporate governance on firm value can be due to many causes. For example, different sources of data (secondary data or survey data) are used in studies. Different methods of measuring firm value variables would achieve non identical study results. 


\section{Research Models and Methods}

\subsection{Research Models}

This study uses the regression models proposed to clarify the impact of GC on EQ of companies as discussed in the literature review, specifically:

$$
\begin{aligned}
\mathrm{FV}_{\mathrm{i}, \mathrm{t}}= & \beta_{0}+\beta_{1} \text { BSIZE }_{\mathrm{i}, \mathrm{t}}+\beta_{2} \text { BDIND }_{\mathrm{i}, \mathrm{t}}+\beta_{3} \text { BMEET }_{\mathrm{i}, \mathrm{t}}+\beta_{4} \text { BDUAL }_{\mathrm{i}, \mathrm{t}}+\beta_{5} \text { BGENR }_{\mathrm{i}, \mathrm{t}} \\
& +\beta_{6} \text { SIZE }_{\mathrm{i}, \mathrm{t}}+\beta_{7} \mathrm{LEV}_{\mathrm{i}, \mathrm{t}}+\varepsilon_{\mathrm{i}, \mathrm{t}}
\end{aligned}
$$

\begin{tabular}{|c|c|c|c|}
\hline Variables & Code & Measurement & Expectation \\
\hline \multirow{4}{*}{ Firm value } & ROA & Profit after tax/Total assets & \\
\hline & EPS & Corporate share price by the end of year $t$ & \\
\hline & TOBINQ & $\begin{array}{l}\text { TOBINQ }=(\text { Market capitalisation }+ \\
\text { Liabilities)/Total assets }\end{array}$ & \\
\hline & PRICE & Corporate share price by the end of year $\mathrm{t}$ & \\
\hline BOD size & BSIZE & Number of BOD members & $+/-$ \\
\hline BOD independence & BDIND & $\begin{array}{l}\text { Number of independent BOD members/Total } \\
\text { number of BOD members }\end{array}$ & $+/-$ \\
\hline $\begin{array}{l}\text { BOD meeting } \\
\text { frequency }\end{array}$ & BMEET & Number of BOD meetings & $+/-$ \\
\hline $\begin{array}{l}\text { BOD chairperson } \\
\text { duality }\end{array}$ & BDUAL & $\begin{array}{l}\text { Equal to } 1 \text { when the } \mathrm{CEO} \text { also holds the position } \\
\text { of BOD chairperson and equal to } 0 \text { in the opposite } \\
\text { case }\end{array}$ & $+/-$ \\
\hline Female ratio on BOD & BGENR & $\begin{array}{l}\text { Number of female BOD members/Total BOD } \\
\text { members }\end{array}$ & $+/-$ \\
\hline Corporate size & SIZE & Log with base 10 of total assets & + \\
\hline Financial leverage & LEV & Total liabilities/Total assets & - \\
\hline
\end{tabular}

Table 1. Description of variables in research models

Source: Built by Author

\subsection{Development of Research Hypothesis}

\section{Board of directors' size (BSIZE)}

Some previous studies have shown that a multi-member BOD will work less efficiently and it will be easier for the CEO to control the company. Coordination and handling of issues that arise in large-sized BODs also entail more costs and this makes decision making difficult (Anderson \& Reeb, 2003; Coles, Daniel, \& Naveen, 2008). In addition, a number of other studies also show that small-sized BODs reduce the "free-riding" problem, thereby enabling enterprises to operate more efficiently and increase firm value (Lipton \& Lorsch, 1992; Yermack, 1996). In this research paper, the BOD size variable will be measured by the number of BOD members and it is expected that the BOD size is positively correlated with firm value. Due to the fact that the difference is too small in the BOD size among companies, which may lead to inaccurate test results, the paper uses the square of BOD size to measure the BOD size variable. Proceeding from the arguments above, the hypothesis about the correlation between BOD size and firm value is:

H1. BOD size has an impact on firm value.

\section{Board of directors' independence (BDIND)}

John \& Senbet, 1998, argued that the BOD would increase its independence by using more independent BOD members. When the enterprise has many independent BOD members, the difference in goals between the manager and shareholders will be reduced. This will make corporate activities more efficient and increase firm value. Nevertheless, a number of other studies have found a negative correlation between BOD independence and firm value (Bhagat \& 
Black, 2002). More and more independent BOD members are now being used by enterprises to improve their corporate performance. Therefore, in this study, the author expects that BOD independence be positively correlated with firm value. BOD independence is measured by the ratio of independent members on BOD of an enterprise. This ratio is calculated by dividing the number of independent BOD members by the total number of BOD members. In this study, the paper uses the square of the ratio of independent BOD members to outcome the too small difference in the member ratio.

\section{H2. BOD independence has an impact on firm value.}

\section{BOD meeting frequency (BMEET)}

The activity intensity variable of the BOD is measured according to the frequency of annual meetings. The author uses the square of the number of BOD meetings to overcome the too small difference in this index and avoid deviations in the research results. Conger et al., 1998, believed that regular BOD meetings would improve corporate performance and increase firm value. Whereas, Vafeas, 1999, observed that BOD meetings were not always helpful. BOD meetings are often entail spending a lot of money, time, as well as remuneration for directors hired from the outside, etc. From the arguments above, the hypothesis about the correlation between the BOD activity intensity and firm value is:

\section{H3. BOD meeting frequency has an impact on firm value.}

\section{The dual position of BOD chairperson and $\mathrm{CEO}$ (BDUAL)}

Research by Ehikioya, 2009, pointed out that conflicts of interest and representation costs are higher when the CEO of an enterprise holds the position of BOD chairperson concurrently. Thus, these two positions should be held by two different people. Nevertheless, Elsayed, 2007, argued that when holding the position of BOD chairperson concurrently, the CEO will be given the opportunity to make decisions without being under any undue impact on the BOD structure. Based on the results of previous studies, this paper will create the variable of CEO duality as a dummy variable (equal to 1 when the CEO holds concurrently the position of BOD chairperson and 0 in the opposite case). This variable is considered as a parameter of the corporate governance variable. The hypothesis given is:

\section{H4. The dual position of BOD chairperson and CEO has an impact on firm value.}

\section{Female BOD members (BGENR)}

Among studies to find out about the impact of female BOD members on firm value, there are studies with an inverse relationship between female BOD members and firm value such as Catalyst, 2004. However, there is also an inverse relationship such as studies by Shrader, Blackburn, \& Iles, 1997, or no impact such as study by Rose, 2007. The hypothesis given is:

\section{H5. BOD female members have an impact on firm value.}

Apart from independent variables in the model, control variables are also considered in the research. Based on the studies by Arora \& Sharma, 2016; Hung, Pham, \& Ha, 2018; Dang et al., 2019, the author introduces control variables into the research model. These variables include: Enterprise size (SIZE) and financial leverage (LEV).

\subsection{Research Data}

The research examines the impact of GC on FV of enterprises listed on Vietnam's stock market during the period 2008-2018, with 2937 observations. The data is collected from financial statements of these companies and the dataset of Vietstock, as well as aggregated from the data published on several reputable securities websites such as cafef.vn or cophieu68.com. The initial data will be synthesized and calculated again in the same way of determining variables, where some variables are regressed to get the remainder and initialize the corresponding new variable through Stata 14.0 software using GLS model.

\section{Research Results and Discussions}

As per the data available in Table 2, Tobin'q index has a mean value of 1.133, the highest is 12.962 and the lowest is 0.121 , standard deviation is 0.843 . Average after-tax return on assets (ROA) is $6.3 \%$, the basic earnings per share is 2.472 thousand dong and the average share price is 21.640 thousand dong. The BOD membership is 5.56 on average, the highest is 13 and the lowest is 3 . The percentage of non-executive independent members of the BOD is $68.0 \%$, the lowest is $20 \%$ and the highest is $100 \%$. The average number of BOD meeting held is 9.925 , of which the lowest rate is 1 and the highest rate is 78 . On average, $24.8 \%$ of enterprises have a BOD chairperson cum CEO. The average percentage of female BOD member is $15.3 \%$. The average size of enterprises by assets after Logarithm is 11.706; the ratio of liabilities to total assets is $50.8 \%$. 
Table 2. Statistical description of corporate governance characteristics

\begin{tabular}{lrrrrr}
\hline \multicolumn{1}{c}{ Variable } & \multicolumn{1}{c}{ Obs } & \multicolumn{1}{c}{ Mean } & \multicolumn{1}{c}{ Std.Dev } & \multicolumn{1}{c}{ Min } & \multicolumn{1}{c}{ Max } \\
\hline TOBINQ & 2937 & 1.133 & 0.843 & 0.121 & 12.962 \\
ROA & 2937 & 0.063 & 0.077 & -0.853 & 0.784 \\
EPS & 2937 & 2.472 & 3.010 & -10.332 & 32.917 \\
PRICE & 2937 & 21.640 & 28.028 & 1.4 & 253 \\
BSIZE & 2937 & 5.560 & 1.344 & 3 & 13 \\
BDIND & 2937 & 0.680 & 0.175 & 0.2 & 1 \\
BMEET & 2937 & 9.925 & 9.435 & 1 & 78 \\
BDUAL & 2937 & 0.248 & 0.432 & 0 & 1 \\
BGENR & 2937 & 0.153 & 0.176 & 0 & 1 \\
SIZE & 2937 & 11.706 & 0.688 & 9.5 & 14.459 \\
LEV & 2937 & 0.508 & 0.214 & 0.004 & 0.993 \\
\hline SOurce: Auhr
\end{tabular}

Source: Author's calculation from Stata 14.0

The autocorrelation matrix is presented in Table 4, showing the direction of impact between the study variables. Firstly, it can be seen that the $\mathrm{BD}$ variable is directly correlated with $\mathrm{EQ}$ of the enterprise, while the AC variable is directly correlated with EQ. At the same time, the purpose of checking the close correlation between independent and dependent variables is to eliminate factors that may lead to multicollinearity before running regression models. The correlation coefficient between independent variables in the model does not have any pair greater than 0.8 , therefore multicollinearity is not very likely to occur, when using the regression model of author group VIF for testing.

Table 3. Correlation matrix

\begin{tabular}{|c|c|c|c|c|c|c|c|c|c|c|c|}
\hline & TOBINQ & ROA & EPS & PRICE & BSIZE & BDIND & BMEET & BDUAL & BGENR & SIZE & LEV \\
\hline TOBINQ & 1 & & & & & & & & & & \\
\hline ROA & 0.2954 & 1 & & & & & & & & & \\
\hline EPS & 0.1573 & 0.726 & 1 & & & & & & & & \\
\hline PRICE & 0.8328 & 0.3337 & 0.3978 & 1 & & & & & & & \\
\hline BSIZE & 0.1045 & 0.0369 & 0.1047 & 0.1715 & - & & & & & & \\
\hline BDIND & 0.1118 & 0.0364 & -0.0115 & 0.0996 & 0.1702 & 1 & & & & & \\
\hline BMEET & -0.0664 & -0.114 & -0.0495 & -0.0874 & 0.0006 & 0.0235 & 1 & & & & \\
\hline BDUAL & -0.048 & -0.0565 & -0.0051 & -0.0357 & -0.0531 & -0.275 & -0.081 & 1 & & & \\
\hline BGENR & 0.0321 & -0.0067 & -0.0471 & 0.0114 & 0.0061 & 0.0484 & 0.0789 & 0.0123 & 1 & & \\
\hline SIZE & 0.0754 & -0.0392 & 0.115 & 0.191 & 0.3475 & 0.0448 & 0.3057 & -0.0152 & -0.0813 & 1 & \\
\hline LEV & -0.1618 & -0.3983 & -0.0902 & -0.155 & -0.0226 & -0.1419 & 0.1943 & 0.0025 & -0.0683 & 0.2863 & 1 \\
\hline
\end{tabular}

Source: Author's calculation from Stata 14.0 
Table 4. Regression results

\begin{tabular}{lrrrr}
\hline & \multicolumn{1}{c}{ ROA } & \multicolumn{1}{c}{ EPS } & \multicolumn{1}{c}{ TOBINQ } & \multicolumn{1}{c}{ PRICE } \\
\hline BSIZE & -0.000264 & $0.126^{* * *}$ & $0.0256^{* * *}$ & $1.377^{* * *}$ \\
BDIND & $-0.0196^{* *}$ & $-0.817^{* *}$ & $0.316^{* * *}$ & $6.899^{* * *}$ \\
BMEET & $-0.000546^{* * *}$ & $-0.0219^{* * *}$ & $-0.00725^{* * *}$ & $-0.405^{* * *}$ \\
BDUAL & $-0.0128^{* * *}$ & -0.123 & $-0.0631^{*}$ & -1.765 \\
BGENR & -0.00827 & $-0.613^{*}$ & $0.166^{*}$ & 4.494 \\
SIZE & $0.0116^{* * *}$ & $0.665^{* * *}$ & $0.165^{* * *}$ & $10.81^{* * *}$ \\
LEV & $-0.152^{* * *}$ & $-1.803^{* * *}$ & $-0.677^{* * *}$ & $-25.52^{* * *}$ \\
cons & 0.0296 & $-4.203^{* * *}$ & $-0.748^{* * *}$ & $-100.5^{* * *}$ \\
\hline $\mathrm{N}$ & 2937 & 2937 & 2937 & 2937 \\
\hline $\mathrm{t}$ statistics in brackets $* \mathrm{p}<0.1, * * \mathrm{p}<0.05, * * * \mathrm{p}<0.01$ & & &
\end{tabular}

Source: Author's calculation from Stata 14.0

Looking at the regression results in Table 4, we can see that the independent variable of BOD size (BSIZE) has a direct relationship with FV, which is represented by EPS, TOBINQ and PRICE. The correlation coefficients are 0.126, 0.0256 and 1.377 respectively, with a level of significance of $1 \%$. The results of this research are consistent with that of the studies by Lipton \& Lorsch, 1992; Yermack, 1996 and contrary to the studies by Anderson \& Reeb, 2003; Coles et al., 2008. Meanwhile, BOD size has no impact on FV when measured by ROA. This indicates that the larger the BOD size, the more precise decisions the BOD will make, as it receives a lot of consultations from the BOD members in discussions, thus contributing to increasing FV.

The research results show that BOD independence (BDIND) has a direct relationship with FV when measured at market price, which is represented by TOBINQ, PRICE, with a coefficient of 0.316 and 6.899 , a level of significance of 1\%; the results of this research are consistent with that of the studies by John \& Senbet, 1998; Brickley et al., 1994; Mashayekhi \& Bazaz, 2008. However, when GV is measured in aspects of book value of ROA and EPS, BOD independence has an inverse relationship with $\mathrm{FV}$, with a level of significance of $1 \%$; the results of this research are consistent with that of the studies by Bhagat \& Black, 2002.

For the variable of the BOD meeting frequency (BMEET) in the year having an inverse relationship with FV, when FV is measured in all aspects of book value or at market price; the results of this research are consistent with the study by Vafeas, 1999, but nonconsistent with the study by Conger et al., 1998. For the factor of dual position of BOD chairperson and CEO (BDUAL), the research results show there is an inverse relationship with FV for the representation variables ROA, TOBINQ, with levels of significance of 5\%,10\% respectively, consistent with the study by Ehikioya, 2009 but inconsistent with the study by Elsayed, 2007. For the two remaining variables, the duality is inversely related with FV but not statistically significant, i.e. there is no difference between enterprises with and without CEOs cum BOD chair-people; this is consistent with the study by Daily \& Dalton, 1997.

The variable of BOD female members has an unclear impact on FV, particularly when FV is measured according to book value, it is inversely related with FV but not statistically significant (a significance level of 10\%). Meanwhile, the ratio of female BOD members is directly related with FV when it is measured at market price but not statistically significant; this research result is consistent with the study by Rose, 2007.

For control variables, the study results also show that enterprise size (SIZE) is also a factor that has a positive impact on $\mathrm{FV}$ in all variables representing firm value with correlation coefficients of $0.0116,0.665,0.165$ and 10.81 , with a significance level of $1 \%$ (p-value equal to 0 ); this research result is consistent with the study by... In addition, the correlation coefficient between the financial leverage (LEV) variable is inversely related with FV, when measured in all aspects of book value and at market price, with a significance level of $1 \%$, indicating that enterprises with lower financial leverage ratio will probably operate more efficiently. Because when the leverage ratio rises too high, it will lay a cost burden on and drive enterprises into financial exhaustion. This research result is consistent with...

\section{Conclusions and Recommendations}

\subsection{Conclusions}

With the research purpose of examining the relationship between GC and FV in Vietnam, the paper uses GC indexes including BOD size, BOD independence, BOD meeting frequency, CEO duality and female BOD members. The 
research assesses the impact of GC on book value (measured by ROA and EPS variables) and market value (represented by Tobin's Q variable and share price) of enterprises. The generalized least squares (GLS) is chosen to use in the study to overcome the problems of variance change and autocorrelation commonly available in datasheets. The main findings in this paper are: Firstly, BOD size has a direct impact on FV (EPS, TOBINQ, PRICE). Secondly, BOD independence has a direct impact on FV, when is measured at market price, but is inversely related with $\mathrm{FV}$, when measured according to book value. Thirdly, BOD meeting frequency and CEO duality are inversely related with FV. Finally, the study results show that the presence of female BOD members does not have an impact on FV in all variables representing FV.

In a word, the results in this paper somewhat show the relationship between GC and FV in Vietnam and this can make it possible for business managers and administrators to apply more appropriate and effective governance measures to contribute to increasing FV.

\subsection{Recommendations}

The research results show the existence of the relationship between GC and FV and the importance of applying GC methods effectively to enterprises in developing countries in general and in Vietnam in particular. The analytical results in the research point out that when companies comply and implement GC well, they can make corporate activity more efficient, reducing representation costs and increasing FV in both terms of book value and market value. Since enterprises in Vietnam are mostly small- and medium-sized, expanding the BOD size can give rise to additional administrative costs, difficulties in unifying and making decisions, as well as conflicts between members. Therefore, the BOD should be built suitable for the corporate size. A reasonably sized BOD can better the coordination between the BOD members, promoting closer supervision and management. However, when the enterprise grows larger in size, operating in more areas, its CEO needs to receive more consultations from the BOD members to make accurate decisions, making it possible for the enterprise to operate more efficiently. By then, expanding the BOD size is an inevitability that enterprises need to do. But in order to ensure that the expansion of the BOD size will bring business efficiency, the BOD members must be competent, experienced people having a thorough knowledge of the scope of operations of the enterprise.

In addition, the inverse relationship between the BOD and firm value (according to book value) is consistent with the viewpoint in the representation theory. In an enterprise, there is always a conflict of interests between directors and shareholders. Directors make actions and decisions for personal goals, do not focus on the goal of maximizing shareholders value, and can cause damage to shareholders. So, the board of directors is set up as a mechanism to monitor activities of directors of the company. The more independent the BOD, the more effective the monitoring mechanism, and the higher firm value (according to market value) will be. Therefore, in order to strengthen the monitoring mechanism and improve operation efficiency, it is necessary to increase BOD independence in the company.

Regarding gender on BOD, if only based on the research results above, it can be concluded that imposing a female BOD ratio is not a good choice for enterprises. The election and appointment of BOD members relied on capacity will be better for business performance and firm value. The percentage of female BOD members in enterprises in survey templates is $15.4 \%$ higher than the world average (12\%). Nevertheless, as the size of BOD in Vietnamese enterprises is small, the average is less than one female member on BOD. This number is probably too small to exert a significant impact on business strategy, thereby increasing FV for enterprises.

Enterprises should expand the form of entering into partnership with partners at home and abroad to have more assets, especially fixed assets with modern technology to operate as well as take advantage of managerial skills, assets and markets of partners to improve firm value. Financial leverage has an inverse impact on FV, i.e. the more enterprises borrow, the more profitability ratio will reduce, and capital structure will also have an inverse impact on firm value. Enterprises, therefore, should be very cautious in mobilizing loan capital, prioritizing equity, and issuing stocks.

\section{References}

Anderson, R. C., \& Reeb, D. M. (2003). Founding-family ownership and firm performance: evidence from the S\&P 500. The Journal of Finance, 58(3), 1301-1328. https://doi.org/10.1111/1540-6261.00567

Arora, A., \& Sharma, C. (2016). Corporate governance and firm performance in developing countries: evidence from India. Corporate Governance, 16(2), 420-436. https://doi.org/10.1108/CG-01-2016-0018

Bhagat, S., \& Black, B. (2002). The non-correlation between board independence and long-term firm performance. Journal of Corporation Law, 27, 231-273. 
Black, B. S., Jang, H., \& Kim, W. (2006). Does corporate governance predict firms' market values? Evidence from Korea. The Journal of Law, Economics, and Organization, 22(2), 366-413. https://doi.org/10.1093/jleo/ewj018

Boyd, B. K. (1995). CEO duality and firm performance: A contingency model. Strategic Management Journal, 16(4), 301-312. https://doi.org/10.1002/smj.4250160404

Brickley, J. A., Coles, J. L., \& Terry, R. L. (1994). Outside directors and the adoption of poison pills. Journal of Financial Economics, 35(3), 371-390. https://doi.org/10.1016/0304-405X(94)90038-8

Brown, L. D., \& Caylor, M. L. (2004). Corporate governance and firm performance. Available at SSRN 586423, 1-52. https://doi.org/10.2139/ssrn.586423

Catalyst. (2004). The bottom line: Connecting corporate performance and gender diversity. Catalyst.

Coles, J. L., Daniel, N. D., \& Naveen, L. (2008). Boards: Does one size fit all? Journal of Financial Economics, 87(2), 329-356. https://doi.org/10.1016/j.jfineco.2006.08.008

Conger, J. A., Finegold, D., \& Lawler, E. E. (1998). Appraising boardroom performance. Harvard Business Review, 76, 136-164.

Core, J. E., Guay, W. R., \& Rusticus, T. O. (2006). Does weak governance cause weak stock returns? An examination of firm operating performance and investors' expectations. The Journal of Finance, 61(2), 655-687. https://doi.org/10.1111/j.1540-6261.2006.00851.x

Daily, C. M., \& Dalton, D. R. (1997). CEO and board chair roles held jointly or separately: much ado about nothing? Academy of Management Perspectives, 11(3), 11-20. https://doi.org/10.5465/ame.1997.9709231660

Dang, H. N., Vu, V. T. T., Ngo, X. T., \& Hoang, H. T. V. (2019). Study the Impact of Growth, Firm Size, Capital Structure, and Profitability on Enterprise Value: Evidence of Enterprises in Vietnam. Journal of Corporate Accounting \& Finance, 30(1), 144-160. https://doi.org/10.1002/jcaf.22371

Detthamrong, U., Chancharat, N., \& Vithessonthi, C. (2017). Corporate governance, capital structure and firm performance: evidence from Thailand. Research in International Business and Finance, 42, 689-709. https://doi.org/10.1016/j.ribaf.2017.07.011

Ehikioya, B. I. (2009). Corporate governance structure and firm performance in developing economies: evidence from Nigeria. Corporate Governance: The International Journal of Business in Society, 9(3), 231-243. https://doi.org/10.1108/14720700910964307

Elsayed, K. (2007). Does CEO duality really affect corporate performance?. Corporate Governance: An International Review, 15(6), 1203-1214. https://doi.org/10.1111/j.1467-8683.2007.00641.x

Fosberg, R. H. (1989). Outside directors and managerial monitoring. Akron Business and Economic Review, 20(2), 24-32.

Freeman, R. E. (1984). Strategic Management: A Stakeholder Approach. Pitman, Boston, MA.

Gompers, P., Ishii, J., \& Metrick, A. (2003). Corporate governance and equity prices. The Quarterly Journal of Economics, 118(1), 107-156. https://doi.org/10.1162/00335530360535162

Hillman, A. J., \& Dalziel, T. (2003). Boards of directors and firm performance: Integrating agency and resource dependence perspectives. Academy of Management Review, 28(3), 383-396. https://doi.org/10.5465/amr.2003.10196729

Hung, D. N., Pham, C. D., \& Ha, V. T. B. (2018). Effects of Financial Statements Information on Firms' Value: Evidence From Vietnamese Listed Firms. Investment Management and Financial Innovations, 15(4), 210-218.

Jensen, M. C. (1993). The modern industrial revolution, exit, and the failure of internal control systems. The Journal of Finance, 48(3), 831-880. https://doi.org/10.1111/j.1540-6261.1993.tb04022.x

Jensen, M. C., \& Meckling, W. H. (1976). Theory of the firm: Managerial behavior, agency costs and ownership structure. Journal of Financial Economics, 3(4), 305-360.

John, K., \& Senbet, L. W. (1998). Corporate governance and board effectiveness. Journal of Banking \& Finance, 22(4), 371-403. https://doi.org/10.1016/S0378-4266(98)00005-3

Lipton, M., \& Lorsch, J. W. (1992). A modest proposal for improved corporate governance. The Business Lawyer, 59-77. 
Mashayekhi, B., \& Bazaz, M. S. (2008). Corporate governance and firm performance in Iran. Journal of Contemporary Accounting \& Economics, 4(2), 156-172. https://doi.org/10.1016/S1815-5669(10)70033-3

Nicholson, G. J., \& Kiel, G. C. (2007). Can directors impact performance? A case-based test of three theories of corporate governance. Corporate Governance: An International Review, 15(4), 585-608. https://doi.org/10.1111/j.1467-8683.2007.00590.x

Peasnell, K. V., Pope, P. F., \& Young, S. (2005). Board monitoring and earnings management: Do outside directors influence abnormal accruals?. Journal of Business Finance \& Accounting, 32(7-8), 1311-1346.

Pfeffer, J., \& Salancik, G. R. (1978). Social control of organizations. The external control of organizations: A resource dependence perspective.

Rechner, P. L., \& Dalton, D. R. (1991). CEO duality and organizational performance: A longitudinal analysis. Strategic Management Journal, 12(2), 155-160. https://doi.org/10.1002/smj.4250120206

Rose, C. (2007). Does female board representation influence firm performance? The Danish evidence. Corporate Governance: An International Review, 15(2), 404-413. https://doi.org/10.1111/j.1467-8683.2007.00570.x

Ross, S. A. (1977). The determination of financial structure: the incentive-signalling approach. The Bell Journal of Economics, 8(1), 23-40.

Shrader, C., Blackburn, V. B., \& Iles, P. (1997). Women in management and firm financial performance: An exploratory study. Journal of Managerial Issues, 9(3), 355-373.

Spence, M. (1973). Job market signaling. The Quarterly Journal of Economics, 87(3), 355-374.

Vafeas, N. (1999). Board meeting frequency and firm performance. Journal of Financial Economics, 53(1), 113-142. https://doi.org/10.1016/S0304-405X(99)00018-5

Xie, B., Davidson, W. N., \& DaDalt, P. J. (2003). Earnings management and corporate governance: the role of the board and the audit committee. Journal of Corporate Finance, 9(3), 295-316.

Yermack, D. (1996). Higher market valuation of companies with a small board of directors. Journal of Financial Economics, 40(2), 185-211. https://doi.org/10.1016/0304-405X(95)00844-5

Zabri, S. M., Ahmad, K., \& Wah, K. K. (2016). Corporate governance practices and firm performance: Evidence from top 100 public listed companies in Malaysia. Procedia Economics and Finance, 35, 287-296. https://doi.org/10.1016/S2212-5671(16)00036-8 